\title{
The National Cultural Security Education of College Students from the Perspective of Expanded In-depth Reform
}

\author{
Fanxing Kong ${ }^{1}$ \\ ${ }^{1}$ Linyi University, Shandong China, 276000
}

Keywords: Deepening reform; College students; Cultural safety education

\begin{abstract}
. $\mathrm{n}$ view of the current development of the concept of innovation as the first, this paper makes a brief analysis of College Students' national cultural safety education, secondly, deepen the reform of the overall view of national cultural security education of College Students under the challenge and the way to improve the cultural level of safety education in-depth analysis. I hope this article can provide some ideas and suggestions for the relevant staff..
\end{abstract}

\section{Introduction}

Under the influence of globalization, the era of cultural globalization has come and greatly impacted on China's outstanding traditional culture. Especially in the university campus, vulgar and philistine culture is more and more popular, which leads to the result that China's traditional culture has been seriously questioned and eroded increasingly. On this basis, it is imminent to reform radically and carry out identity education of outstanding traditional culture of college students and maintain the country and nation's cultural security. Based on this, this paper combines with the theory and practice, carries out the following analysis of the national cultural security education of college students from the perspective of expanded in-depth reform.

\section{The importance of cultural safety education}

It's conducive to safeguarding national security.The so-called national cultural security refers to the mainstream value system of the country, and ideology, basic life system, social civilization, excellent quality, knowledge system, religious belief, formed based on that, should not be destructed and subverted by internal or external forces, to ensure that the country has complete cultural sovereignty, and to provide a steady stream of spiritual power for the country's social and economic stability." National cultural security education in major colleges and universities not only can stimulate the sense of responsibility and mission of college students to give up their own interests for national security initiatively in the face of national crises, but also can promote college students to realize the importance of cultural security of China and fundamentally improve their identification for various information. Therefore, it is of great significance to carry out the national culture education in colleges and universities to ensure the stable development of the country.

It's conducive to the healthy growth of the college students. The college students were born in 1990s, they are in the era of reform, development, and information, very easy to be influenced by cultures of other countries, for example: after tasting foods in McDonald's and Pizza Hut they will be interested in fast food culture; after enjoying Hollywood blockbusters and literary works, their vision and thinking will be influenced, which will gradually change college students' mode of thinking, and even lead to their worship and imitation of other countries in their lives. However, they are not aware of the different development levels between different countries, for example, the 
western developed countries advocate carpe diem, but this way of life is not suitable for our country's basic conditions, if they are not educated and guided scientifically and reasonably, foreign culture and ideas will have great influences on college students, and even destroy them. In the philosophy that "if young persons are thriving, the country will be thriving; if young persons are powerful, the country will be powerful ", contemporary college students are endowed with the responsibility of realizing the great national revival, therefore, to carry out the national cultural security education in university teaching is of practical significance [1].

\section{The challenge of cultural security education}

language collision. The main way of the inheritance of the national culture of the language is also the traditional excellent culture of a country. For our country, language not only embodies the connotation of culture, but also is the main symbol of national culture. China has 5000 years of cultural history, which contains the wisdom, civilization, customs, history, religion, etc. in the past 5000 years in our country. In the context of reform and development, a large number of foreign languages come into our country, and the training institutions are springing up everywhere. However, if ignoring the study of Chinese when learning a foreign language, they will be affected by other countries' cultures. For example: the major colleges and universities offer Japanese, Korean, German and other professional courses loved by a lot of college students. But no one shows any interest in Chinese, the specialty representing the traditional culture of China. Chinese and foreign languages are contesting in the major colleges and universities in China, which stunts the national cultural security education for college students, and is one of the problems to be urgently solved currently [2].

Aesthetic change. Relevant experts and scholars said that the aesthetic approach is the main embodiment of values, also one of the ways of embodiment of national culture. In recent years, college students' aesthetic style has been changed greatly, which leads to the shake of the foundation of the traditional Chinese culture. The university is the learning stage with the least stress, they don't worry about the entrance examination, they have a lot of extra time, and they have a deeper understanding of global popular culture in the era of information. Such as: cultures of Japan and South Korea. Since the end of 1990s, pop cultures of Japan and South Korea have been lasting and their impacts on our college students are becoming increasingly serious. South Korean TV soaps, Japanese comics, idolatry have become a part of college students' lives, some college students are even obsessive with cultures of Japan and South Korea, which leads to the result that current college students' aesthetic standard becomes increasingly like the aesthetic standard of Japan and South Korea. If these problems are not resolved well, college students will worship everything foreign, and Chinese traditional culture will be inherited and carried forward by no one [3].

Westernized consumption. In the context of global economic integration, as the main symbol and representative of a country, the culture is gradually changed by economy and commerce. Western countries use their own cultural products to penetrate Chinese college students' outlook on life, values, and social values gradually. Because many college students are lack of cognition and judgment, blindly accept and deliberately imitate the western way of life and consumption patterns, but they do not analyze their real situations, and form the life concept and consumption patterns of enjoying-life timely and money supremacy. According to incomplete statistics, the "Lei Feng spirit" is gradually being replaced by "egoism" in major colleges and universities. In major colleges and universities, college students often drop litter, destroy teaching facilities carelessly, and teachers often clean the blackboard by themselves. College students do not have the spirit of dedication, live as they please, take their scorns for stipulates and disciplines of school as publicity personality. If 
the western consumer culture cannot be changed, finally, college students will be assimilated by western culture. College students are the main force of the sustained and stable development of China's society and economy. Once the consumption mode is westernized, China's socialist construction will be greatly influenced.

\section{Ways of Education}

Strengthening the education of crisis consciousness and enhancing the consciousness of national cultural security. Psychologists said that consciousness is the main driving force of human action. So in order to improve national cultural security education for college students in the perspective of expanded in-depth reform, we must strengthen the consciousness of national cultural security education for college students, and promote Chinese college students to clearly understand the current threats and challenges for national cultural security education. The related practices and experiences show that, consciousness of cultural security and consciousness of cultural crisis have very close relationship. Crisis consciousness is the premise of security consciousness, if lack of crisis consciousness, security consciousness will certainly be reduced. In the threats of foreign cultures, scientific and reasonable improvement of crisis consciousness of college students for national cultural security education will strengthen their sense of urgency and responsibility for Chinese culture to a large extent, so that they can actively safeguard national cultural security. So the education departments should strengthen the education of crisis consciousness for college students, so as to make every college student establish the concept of "everyone is responsible for national cultural security, " fundamentally guarantee the full development and inheritance of traditional culture of our country, and lay a solid foundation for China's economic and social development [4].

Carrying forward the excellent culture of the Chinese nation and sticking to the cultural foundation. The main reason why foreign culture could permeate and impact on college students' values is the lower traditional cultural values of college students. So in the development of national cultural security education for college students, we must inherit and carry forward our national history and culture, cultivate their identity and pride for excellent traditional culture, and take the importance of the development of national culture as the main content of education. On the basis of inheriting, reforming and innovating the excellent national culture, we can create cultural products which can not only reflect the Chinese characteristics, but also be close to the actual life of college students. For example: organizing different types of cultural teaching activities on traditional festivals in China, and developing and using traditional cultural resources by modern high-tech. Through the Internet technology, penetrate the achievements of traditional culture of China into the corresponding cultural products to strengthen college students' identity and pride for excellent national culture and their sense of responsibility and mission for achieving the great rejuvenation of the nation.

Building a security platform for network culture, optimizing the network environment. The Internet increasingly impacts on people's lives, learning, education, etc. As one of the places holding the densest netizens, colleges and universities must strengthen the management of network culture to minimize the negative influences brought by the Internet and maximize network's function and value. At the same time, colleges and universities should establish relevant laws and regulations to restrain the behaviors of college students online, infiltrate excellent traditional culture of the country into the network culture with the help of Internet tools, fully integrate the network media, such as campus network, BBS, post bar, etc., through the function of the computer and Internet, implement the concept and importance of the national cultural security education in every 
aspect of college students' learning and campus life, expand the communication scope of network media and build the communication system of national cultural security education of its own. [5]. So as to further deepen the national cultural values and communication with the help of network platform, encourage college students to actively learn the national culture security courses and open up new spaces for college students' national cultural security education with the help of the diversity and virtuality of network platform from the perspective of expanded in-depth reform.

\section{Concluding remarks}

To sum up, by the in-depth analysis of the national cultural security education of college students from the perspective of expanded in-depth reform, this paper draws the following conclusions:

1)The implementation of the national cultural security education for college students has a very important significance for safeguarding national security, promoting the healthy growth of college students, and the inheritance and development of national culture, which is urgently needed by college students.

2)Although it is of great significance to carry out the national culture security education of college students, the research on the national culture security education of college students in China has yet to be further improved. In the course of the actual education, there are still problems, such as: language collision, aesthetic change, and westernized consumption.

3)The ways which are put forward to improve the national culture security education of college students from the perspective of expanded in-depth reform, are to ensure that our national traditional culture can be successfully developed and inherited.

\section{Reference}

[1] Guo Yaping, Gao Rudong. On ideological and political education of minority college students in Xinjiang province from the perspective of cultural security[J]. Journal of Tarim University, 2014, (4):111-116.

[2] Wang Lingzhi. National security education of college students under the background of extensive network[J]. Journal of Yichun University, 2014, (11):20-24.

[3] Li Shaoqi. On the ideological education of college students for the impact of thoughts of western social under the perspective of cultural security [J]. Journal of Southwest University for Nationalities (Humanities and Social Sciences Edition), 2015,(8):225-230.

[4] Zhang Jie, Wang Huidan. The core values education of college students in Xinjiang from the perspective of cultural security [J]. Heilongjiang Education(Higher Education Research \& Appraisal), 2014,(7):83-85.

[5]Ma Xuechun. On the traditional culture identity education of college students from the perspective of cultural security strategy [J]. Heilongjiang animal husbandry and veterinary medicine [5], 2016,(16):264-268. 